\title{
エポキシ樹脂の絶縁塗料への応用 $\begin{aligned} & \text { UDC } \\ & : 627.637 .413 .33 .263 .3\end{aligned}$ \\ $: 678.643$
}

\section{Application of epoxy resins to insulating varnishes}

\author{
入 貝 信 一* \\ IRIGAI $\operatorname{Sin}^{\prime}$ iti
}

\begin{abstract}
1. まえがき
エポキシ樹脂塗料の優秀性は広く一般に認識されて抹 り，すでに耐薬品塗料，耐熱塗料として各種機械装置類 の保護塗料, パイプラインや化学装置の防食, 自動車な ぞのプライマーとして多くの実績をもっている。絶縁塗 料の面では土ポキシ樹脂塗料の需要はまだ決して多いと はいえない。しかしその優秀な特性はすでに電気機器の 進歩に大きく貢献しているし，今後ますます重要な材料 となるであろう。

エポキシ樹脂は在来の溶剂形塗料としてもすぐれた性 能を発揮しているが，さらに無溶剤ワニスとして特に電 気絶縁方面に重要な役割をはたしている。また最近は粉 末状塗料として流動浸漬法 (Fluidized-Bed Coating), 粉末噴射塗装 (Powder Spray Coating) などによって 新境地を開きつつある。これらのすべてに触れることは 紙面が許さないので，ここでは主として溶剤形塗料につ いて絶縁塗料としての立場から眺めてみたい。
\end{abstract}

\section{2. 絶緑塗料に要求される性能}

塗料といっても一般塗料と絶縁塗料では要求される性 能に大きなちがいがある。その主な点をあげてみると次 のと括りである。

浸透性・安定性 絶縁塗料である以上は電気的特性が 重要なことはもちろんであるが，細い銅線が密に何層も 巻かれたコイルや, マイカ, 紙などで構成された厚い絶 縁層を通して内部までよく浸透しなければならない。そ れには真空含浸などの方法も採られるが塗料粘度の低い ことが望ましい。

また絶縁処理は多くの場合浸漬法で行なわれる。した がって塗料は長期祆たって安定で粘度変化を起こさな いことが大切である。

内部硬化之耐熱軟化 ワニス処理の目的の一つはコイ ルの固着である。ゆえに浸透した塗料は乾燥によって内 部まで一様に硬化することが必要である。電気機械は運

昭 37. 11. 30. 受理

*1東京芝浦電気株式会社中央研究所

\begin{tabular}{|c|c|}
\hline 絶縁の種類 & $\begin{array}{c}\text { 許容最高温度 } \\
\left({ }^{\circ} \mathrm{C}\right)\end{array}$ \\
\hline Y & 90 \\
\hline A & 105 \\
\hline $\mathrm{E}$ & 120 \\
\hline B & 130 \\
\hline $\mathrm{F}$ & 155 \\
\hline $\mathrm{H}$ & 180 \\
\hline C & 180 超過 \\
\hline
\end{tabular}

転中:回転や振動, 衝撃を 受けるほか，多くの場合発 熱を伴う。したがって温度 が上ったときに軟化して接 着力が弱をることは好まし くない。

耐熱性 電気学会では電 気機器の耐熱特性について 表1のように絶縁の種類を 定め，それぞれの種類に応 じて使用し得る絶縁材料を 定めている11。たとえば B 種絶縁の機器を造る場合, $130^{\circ} \mathrm{C}$ で長期間運転されても，それを処理してある塗料 皮膜はその機能を十分に保っていなければならない。

熱劣化の結果塗膜に起こる現象としてはワレの発生, 発泡, 脆化, 変色, 肉やせなどがあるが, 一般汇㴽脆 を重視して拈り，先の判定を皮膜の屈曲性によって行っ ている。

耐湿性 吸湿による絶縁の低下といらことは電気機器 に多い事故である。ゆ元に附湿性のよいことは絶縁塗料 として重要な条件である。

以上のほか機種によっては耐油性, 耐薬品性, 耐候 性, 耐アーク性, 耐コロナ性などを必要とする場合があ る。

\section{3. エポキシ樹脂塗料の形態}

エポキシ樹脂の特長の一つ注, その塗料化活種々の方 式があることである。これを大別すると次の 4 種代分類 されるであらう。

1. 原形樹脂々硬化剂を使 万方法

2. 他の樹脂類を配合し，これ硬化剂学併用する方 法

3. 他の樹脂と共縮合させる方法

4. エステル化する方法

これらの方式は接着剤, 積層板の製造その他の形で電 気機器に利用されているが，コイル含浸ワニスだけを対 象とした場合はポットライフその他の点で，必ずしも利 
用できるとはい它ない。ただ（4）を除けば大体使用者 自身で調合できるという点に一つの興味がもたれる。最 近グリシジールエーテル形以外の多くのエポキサイドが 開発されているが，これらも皆前記の方法のいずれかに よって塗料化される。

\section{4. 原形樹脂と硬化剂を使う方法}

硬化剈を使う方法はエポキシ樹脂硬化の最も基本的な 方法で㐫る。しかし絶縁塗料としては種々問題も㐫り現 在のところ利用度はあまり多くない。

\section{1. 脂肪族アミン類}

最も活性が大きく，比較的低温で乾燥することは一つ の鬽力であるが，ポットライフの短いことが大きな欠点 である。硬化皮膜の耐湿性, 電気特性もあまり良好々は 思えない。ぬたアミンは銅と反応して変色を起こす可能 性があり，この点も好ましくない。

ただ速乾性でめり，接着力が大きいため，組立工作に おいて接着剤に利用することが考穴られる。また耐油性 仕上げ塗料としての用途があろう。

\section{2. 芳香族アミン類}

ポットライフは前者より長いがやはりコイル処理には 使觉ない。電気的性質・耐熱性なぞは前者よりすぐれて いる。またいわゆる Bステージの状態を通って硬化する ので積層板製造用として使われている。ガラスクロスを 基材とした積層板は各種絶縁用として使われている。

ただアミン系硬化㨈はエポキシ基の化学当量より少し でも過剩使うと電気的に有害であり, 後刻問題を起こ すことがあるから注意しなければならない。な就芳香族 アミンではないが，ピペリジンで硬化したものは電気特 性ぶすぐれている。

\section{3. 三フッ化ホウ素錯塩}

ポットライフが比較的長く, 一カ月以上安定であるが コイルワニスとしてはな拉不十分である。また硬化温度 がかなり高いことが難点である。しかし電気特性がよ く, 耐熱性も高いので使い方によっては絶縁塗料に利用 できるで出らう。な招最近ホウ素化合物で潜在性硬化刘 （ある温度以上にならないと反応しない)が開発されつつ あり, 塗料用として期待される。

\section{4. イソシアネート}

イソシアネートはエポキシ基とは直接反応しない。し たがって氷酸基その他の活性基をもつエポキシ樹脂を使 らか, 活性基をあらかじめ樹脂に付与して抢く必要が宓 る。活性イソシアネートを使う場合には二液形の塗料と なり,ポットライフは 1 日ないし数日となる。安定化し たイソシアネートの場合には一液形塗料を造ることがで きるが，これは焼付けに $180^{\circ} \mathrm{C}$ 程度の温度を要する。乙 たがっていずれの場合もコイル処理ワニスとしては問題 ぶある。またイソシアネート硬化の樹脂は一般にたわみ 性があまり十分でないことも欠点の一つである。

\section{5. 無水カルボン酸}

アミン類と比べるとポットライフが長く, 硬化後の電 氛的特性・機械強度・耐熱性なぞがすぐれているが，硬 化には高温長時間を要する。現在のところ無溶剤ワニス の形で注形用材料として重要なものであるが，溶剤形ワ ニスとしてはほとんど利用されていない。表2に沶もな 無水カルボン酸を使った場合の特性を示す。

\section{5. 配合 (ブレンド) 方式}

エポキシ樹脂に他の合成樹脂類を混合し，これと硬化 剤を加える方法である。この方法によってエポキシ樹脂

表 2 無水カルボン酸で硬化した Epikote 828* の特性

\begin{tabular}{|c|c|c|c|c|c|c|c|c|c|}
\hline & \begin{tabular}{|l|} 
絶縁破壊 \\
電 \\
$\mathrm{kV} / \mathrm{mm}$ \\
$\mathrm{k}$
\end{tabular} & $\begin{array}{l}\text { } \\
1 \mathrm{kc} \\
25^{\circ} \mathrm{C} \\
\end{array}$ & $\begin{array}{c}\text { 電 } \\
1 \mathrm{kc} \\
100^{\circ} \mathrm{C}\end{array}$ & $\begin{array}{l}\text { 率 } \\
1 \mathrm{Mc} \\
25^{\circ} \mathrm{C}\end{array}$ & $\begin{array}{l}\text { 誘 } \\
1 \mathrm{kc} \\
25^{\circ} \mathrm{C}\end{array}$ & $\begin{array}{c}\text { 電 正 } \\
1 \mathrm{kc} \\
100^{\circ} \mathrm{C}\end{array}$ & $\begin{array}{l}\text { 接 } \\
1 \mathrm{Mc} \\
25^{\circ} \mathrm{C} \\
\end{array}$ & $\begin{array}{c}\text { 体 積 } \\
\text { 抵抗 } \\
\Omega \mathrm{cm}\end{array}$ & $\begin{array}{l}\text { 熱変形 } \\
\text { 温 }{ }^{\circ} \text { 度 } \\
{ }^{\circ} \mathrm{C}\end{array}$ \\
\hline $\begin{array}{l}\text { Hexahydrophthalic } \\
\text { anhydride }\end{array}$ & 一 & 2.95 & - & 3.05 & 0.009 & - & 0.010 & $3.8 \times 10^{15}$ & 128 \\
\hline Methylnadic anhydride & - & 一 & - & 3.2 & - & 一 & 0.019 & 一 & 一 \\
\hline Chlorendic anhydride & - & 3.3 & - & 3.1 & 0.006 & - & 0.018 & - & 188 \\
\hline $\begin{array}{l}\text { Dodecenylsuccinic } \\
\text { anhydride }\end{array}$ & - & 2.80 & 3.75 & 2.71 & 0.006 & 0.010 & 0.008 & - & 78 \\
\hline Phthalic anhydride & 16.5 & 3.65 & - & - & 0.002 & - & - & $>8 \times 10^{13}$ & 149 \\
\hline $\begin{array}{l}\text { Pyromellitic dianhydride } \\
+ \text { Nadic anhydride }\end{array}$ & 14.0 & 3.97 & 4. 48 & 3.34 & 0.01 & - & 0.027 & $0.1 \times 10^{15}$ & 230 \\
\hline $\begin{array}{l}\text { Pyromellitic dianhydride } \\
+ \text { Chlorendic anhydride }\end{array}$ & 14.8 & - & - & 3.15 & - & - & 0.014 & $10 \times 10^{15}$ & 125 \\
\hline
\end{tabular}

$\overline{38[4]}$ 
の一部の欠点がカバーされるが，同時にとの特長を失う ことも㐫り，配合する樹脂の選択が大切である。ポット ライフは同じ硬化剤を使った場合，配合しないものより わずかに長くなる。颃子な配合樹脂の特性学 3 に示 于。

表 3 他の樹脂を配合したエポキシ樹脂の特性

\begin{tabular}{|c|c|c|c|}
\hline & $\begin{array}{l}\text { チオコール } \\
(\text { 多硫化ゴム) }\end{array}$ & $\begin{array}{l}\text { アジプレン-L } \\
\left(\begin{array}{l}\text { ポリウレタ } \\
\text { ンゴム }\end{array}\right)\end{array}$ & $\begin{array}{l}\text { 塩 } \text { 化 } \\
\text { ビニル }\end{array}$ \\
\hline $\begin{array}{l}\text { 配 合 量 } \\
\left(\begin{array}{c}\text { エポキシ樹脂 } \\
100 \text { 部に対し }\end{array}\right)\end{array}$ & 50 & 100 & $200 *$ \\
\hline 硬化 剂 & 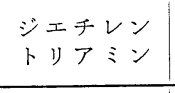 & $\begin{array}{l}\text { メチレン・ } \\
\text { ビスクロロ } \\
\text { アニリン }\end{array}$ & $\begin{array}{l}\mathrm{BF}_{3} \text {-ピペ } \\
\text { リジン }\end{array}$ \\
\hline ポットライフ & $15 \sim 20$ 分 & - & 約 15 日 \\
\hline 体積抵抗率 $\Omega \mathrm{cm}$ & $10^{12} \sim 10^{13}$ & $2.5 \times 10^{14}$ & $3 \times 10^{13}$ \\
\hline 誘電率 $(1 \mathrm{kc})$ & $4.5 \sim 5.0$ & 4.7 & - \\
\hline 誘電正接（1 kc） & $0.015 \sim 0.03$ & 0.018 & - \\
\hline
\end{tabular}

* 他に DOP 60 部を添加

\section{1. 多硫化ゴム}

チオコール2) を配合することは早くから行なわれてい る。チオコールの添加は樹脂に弾性を与え, たわみ性の 改善に著しい効果を示すが，電気特性が相当低下するの が大きな欠点である。

\section{2. ポリウレタンゴム}

液状のポリウレタンプレポリマー- (Adiprene, Du Pont $)^{3)}$ は土ポキシ樹脂に溶け，かつ共通の硬化剤（ア ミン類）によって共重合の形で硬化する。チオコールと 同様にエポキシ樹脂のたわみ性を向上するだけでなく， 電気特性を低下させない点ですぐれている。コイルワニ スとしては不適当であるが，他の面で利用価值があろ 万。

\section{3. ビニルプラスチゾル}

最近 UCC 社が発表したもので, 塩化ビニル粉末をエ ポキシ樹脂 (Unox 201) 中に分散したものである。必要 によって DOP その他の可塑剤, 溶剂も添加される。硬 化剂としては $\mathrm{BF}_{3}$ などが使われる。硬化に高温を要す るがたわ文性, 耐薬品性のすぐれた皮膜が得られる。浸 漬法によって一度に厚い皮膜をつけることが可能でめり 仕上塗料として興味が岁る。

\section{4. 不飽和ポリエステル}

エポキシ樹脂に通常の不飽和ポリエステルを混合する 方法で, 硬化には両者の硬化剤を併用する必要がある。 ポリエステルの適当なものを選べば粘度の低下, コスト ダウンなどの面で効果がありコイルワニスに適したもの
が得られるであろ5。逆に選び方が悪いと中途半端な塗 料となって利用価値のないものとなる。

\section{6. 共縮 合方式}

分子中に官能基をもつ高分子化合物を加え，エポキシ 樹脂と架橋反応させて硬化する方法で, すでに耐薬品塗 料, 耐熱塗料などとして広く利用されている。める種の ஓのは絶縁塗料としての実績もあり，エポキシ樹脂塗料 の中でも重要なものである。

\section{1. ポリアミド樹脂}

液状ポリアミド樹脂は多くの活性基を含んで和り，工 ポキシ樹脂硬化剤として重宝なるのである。すでに接着 剤, 塗料, 湿式による積層品の製造など各方面に応用さ れている。二液性であることが難点であるが，作業性は． よく，常温でも硬化することが特長である。皮膜はたわ み性, 付着性がすぐれ, 耐油, 耐薬品性も良好である。

コイルワニスとしてはポットライフが短いこと，耐熱 性がやや低いことが難点である。しかし耐油性仕上げ塗 料としてすぐれている。皮膜の電気特性は表 4 のように 良好である。

表 4 共縮合形エポキシ塗料の特性

\begin{tabular}{|c|c|c|c|}
\hline 混 合 樹 & 脂 & 尿素樹脂 & 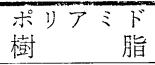 \\
\hline 乾 燥 時 間 & $(\mathrm{h})$ & $1\left(160^{\circ} \mathrm{C}\right)$ & $\begin{array}{r}12(\text { 常 温) } \\
1\left(100^{\circ} \mathrm{C}\right)\end{array}$ \\
\hline $\begin{array}{c}\text { 体積抵抗率 } \\
(\Omega \mathrm{cm})\end{array}$ & $\begin{array}{l}\text { 常 態 } \\
\text { 浸水後 }\end{array}$ & $\begin{array}{l}1.4 \times 10^{16} \\
3.9 \times 10^{15}\end{array}$ & $\begin{array}{l}6.2 \times 10^{15} \\
1.1 \times 10^{15}\end{array}$ \\
\hline $\begin{array}{l}\text { 絶緑破壞電压 } \\
(\mathrm{kV} / 0.1 \mathrm{~mm})\end{array}$ & $\begin{array}{l}\text { 常 態 } \\
\text { 浸水後 }\end{array}$ & $\begin{array}{l}13.2 \\
12.8\end{array}$ & $\begin{array}{l}11.0 \\
11.1\end{array}$ \\
\hline
\end{tabular}

注 電気試験片はいずれも $160^{\circ} \mathrm{C}, 3$ 時間焼付けた。

\section{2. アミノ樹脂}

ブチル化した尿素樹脂, メラミン樹脂なぞも水酸基壳 持つエポキシ樹脂と共縮合する。その暁付け皮膜は光沢 に富み, 強じんで耐熱性, 耐薬品性犯すぐれ, 金属の保 護塗料として優秀なものである。委たポットライフが長 く, 通常 6 カ月以上安定である。ただ焼付汗温度が高く 尿素の場合 $160^{\circ} \mathrm{C}$ 以上, メラミンでは $180^{\circ} \mathrm{C}$ 以上を必 要とするため, 絶縁塗料としての用途はかなり制約をう ける。耐熱積層板の製造やエナメル線用ワニスとして利 用できるであろう。なお皮膜としての特性はメラミンの 方がすぐれているが，エポキシ樹脂との相溶性で尿素樹 脂の方が多く使われる。特性の一例を表 4 に示した。

\section{3. フェノール樹脂}

フェノール樹脂もエポキシ樹脂と反応して付着性, 耐 熱性・耐薬品性の優秀な皮膜を形成する。フェノール樹 
脂としてノボラック形・レゾール形特よびブチル化した もののいずれも使われるが，相溶性の点で制限される。 ただし単に混合しただけでは相溶性がなくても予備縮合 を行ならことによって相溶性となる場合がある。予備縮 合はフェノール樹脂のみでなく, アミノ樹脂の場合にも 皮膜の性能向上に大きな効果がある。

フェノール樹脂もアミノ樹脂と同様に焼付温度が高い ため用途が制限される。しかしエナメル線塗料, コアワ ニスなどとして検討する価値があろう。

\section{4. 酸性ポリエステル}

ポリエステル（なたはアルキド樹脂）を製造する場合 飞理論量より過剩のカルボン酸を使うと, 分子末端にカ ルボキシ残基をるった比較的分子量の小さい樹脂が得ら れる。このカルボキシ残基は無水カルボン酸と同様にエ ポキシ樹脂と反応してこれを硬化させる。しかも無水カ ルボン酸と比べると反応性が非常に低いためポットライ フが長い。委た硬化樹脂の性質はポリエステルの組成に よって異なるが一般に付着性, たわ文性がすぐれ，電気 的特性，耐熱性なぞもすぐれている。

表 5 酸性ポリエステル・エポキシ塗料の特性

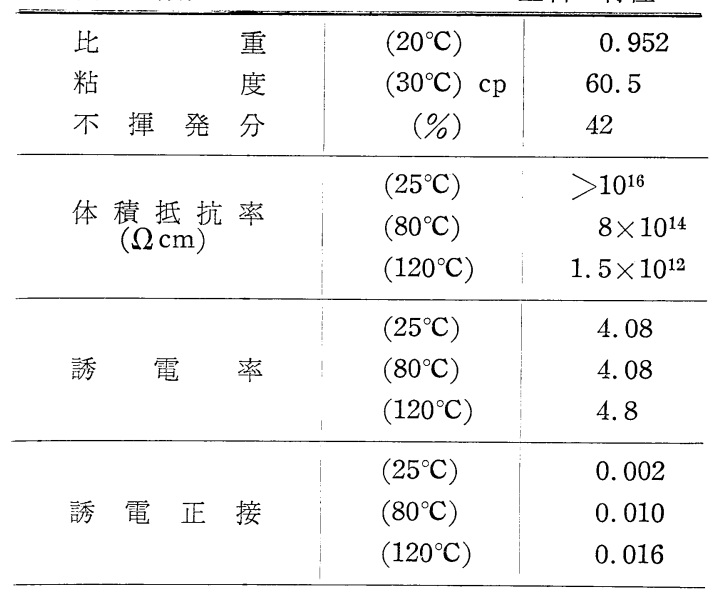

したがってコイルワニスとしての適応性をもって打 り，その他マイカ製品の製造にも使われる。すで炏 発電機のような大形電気機器を始め, B種絶縁回転機の コイル処理に使われて叔り，その優秀な性能は高く評価 されている。その特性の一例を表 5 亿示す。ワニス処理 の工程も従来のワニスとほとんど同じ方法が適用でき る。ただ乾燥温度は高く, $150^{\circ} \mathrm{C}$ 程度が必要である。つ ぎにその製法の一例)を示す。

アジピン酸 $2 \mathrm{~mol}$ とエチレングリコール $1 \mathrm{~mol}$ を加 熱縮合させて酸価約 350 の酸性ポリエステルを造る。エ ボキシ樹脂（エピコート 1004 程度のもの） 1 当量に対
して上記ポリエステル 0.8 ないし 1.5 当量を加光, キ シレンその他の溶剤でらすめる。このワニスは $160^{\circ} \mathrm{C}$, 3 時間以内で硬化する。

酸性ポリエステルの代りに酸性不飽和ポリエステルを 造り, これとエポキシ樹脂を縮合したのち, 過酸化物触 媒を加えて硬化させる方法も発表されている5)。また中 性のポリエステルをエポキシ樹脂と混合し、これに無水 カルボン酸を加えて硬化する方法るある。

\section{5. シリコーン樹脂}

エポキシ樹脂とシリコーンの共縮合樹脂に関していく つかの方法が発表されているが，その中で J.R. Bond ら の報告6) は與味あるるのである。この報告では土ポキシ 樹脂として比較的低分子量でかつ水酸基をるつものを使 っている。水酸基を持たない場合湾は反応開始剂を加兄 る必要が岕る。またシリコーンとしてはフェニル基拉よ び活性シラノール基を含む低分子量のものを用いる。

製造方法は簡単であって, これらの原料を共通溶剂中 で加熱すれば脱水縮合を起して共縮合体が得られる。生 成した共縮合樹脂は分子中にエポキシ残基をもってい る。したがってその硬化は一般のエポキシ樹脂と全く同 じで，硬化剤によって行なわれる。

硬化樹脂の特性はシリコーンの混合比 $25 \%$ 前後のも のが最も良好で，その機械的特性はエポキシ樹脂単独の 場合よりすぐれている(図 1参照)。その他電気的性質や 耐熱性の点でもこの組成のものが良好である。たでし耐 熱性は硬化剂の影響を受け，特に耐熱性に重点を置く場 合にはメチルナディックアンハイドライドなどが適して 拉り，午の他メタフェニレンジアミンる使われる。表 6 はメタフェニレンジアミンを硬化㓣とし，ガラスクロス を基布とした積層板の特性である。

シリコーンーエポキシ樹脂叙料の用途はとの耐熱性を

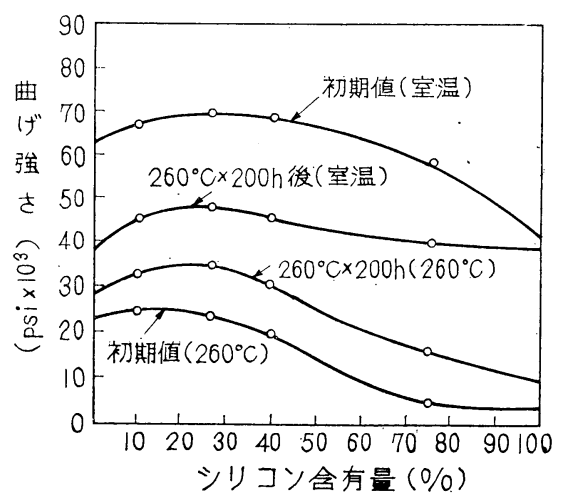

図 1 シリコーンエポキシ樹脂のシリコーン含有量と 曲げ強さ 
表 6 シリコーンーエポキシ樹脂積層板の特性

\begin{tabular}{|c|c|c|c|c|c|}
\hline シリコ & ーン含有量 & $(\%)$ & 0 & 25 & 50 \\
\hline 曲げ強さ & 初 期 值 & $\begin{array}{l}\text { 室 温 } \\
260^{\circ} \mathrm{C}\end{array}$ & $\begin{array}{r}5,250 \\
428\end{array}$ & $\begin{array}{r}5,660 \\
840\end{array} \mid$ & $\begin{array}{r}4,750 \\
585\end{array}$ \\
\hline$\left(\mathrm{kg} / \mathrm{cm}^{2}\right)$ & $\begin{array}{c}260^{\circ} \mathrm{C} \times 500 \mathrm{~h} \\
\text { 加 熱 後 }\end{array}$ & $\begin{array}{l}\text { 室 温 } \\
260^{\circ} \mathrm{C}\end{array}$ & ふくれる & $\begin{array}{l}4,430 \\
1,260\end{array}$ & $\begin{array}{l}3,300 \\
1,220\end{array}$ \\
\hline $\begin{array}{r}\text { 絶縁石 } \\
(\mathrm{kV})\end{array}$ & $\begin{array}{l}\text { 破壞電圧 } \\
\mathrm{V} / \mathrm{mm})\end{array}$ & $\begin{array}{l}\text { 気 中 } \\
\text { 油 中 }\end{array}$ & $\begin{array}{r}9.3 \\
15.6\end{array}$ & $\begin{array}{r}9.6 \\
12.8\end{array}$ & $\begin{array}{r}9.3 \\
14.3\end{array}$ \\
\hline 誘 電 & 率 $(60 \mathrm{c} / \mathrm{s})$ & $\begin{array}{l}\text { 常 態 } \\
\text { 浸水後 }\end{array}$ & $\mid$\begin{tabular}{c|}
5.70 \\
剆定不能
\end{tabular} & $\begin{array}{l}4.70 \\
5.28\end{array}$ & $\begin{array}{l}4.68 \\
5.88\end{array}$ \\
\hline 誘電正打 & 接 $(6 \mathrm{~J} \mathrm{c} / \mathrm{s})$ & $\begin{array}{l}\text { 常 態 } \\
\text { 浸水後 }\end{array}$ & $\begin{array}{c}0.024 \\
-\end{array}$ & $\begin{array}{l}0.006 \\
0.004\end{array}$ & $\begin{array}{l}0.008 \\
0.07\end{array}$ \\
\hline 耐アー & ク性 (sec) & & 15 & 160 & 150 \\
\hline
\end{tabular}

いかした積層板の製造であるが，適当な硬化剂を選べば $\mathrm{H}$ 種絶縁用塗料としての利用も可能であうう。また注形 用樹脂についても発表されている7)。

\section{7. エステル化塗料}

エポキシ樹脂塗料として最も沉用性に富むものであ り，一般保護塗料としてすで各方面に広く使われてい る。その製造方法はアルキド樹脂塗料とほとんど同じ で，したがってアルキド樹脂の製造装置をとのま転用 することができる。ただエポキシ樹脂の場合は脂肪酸と のエステル化に高温を必要とするため, 支那キリ油のよ うな乾燥性の早い植物油を使らことは困難である。

エポキシェステルの特性はアルキド樹脂としばしば比 較されるが，同じ脂肪酸を使った同じ程度の油長の塗料 を両者比べてみると, 次の点でエポキシェステルの方が すぐれている。

1. 酸価が非常に小さい。

2. 電気絶緑性がすぐれている。

3. 耐水性がよく, 耐薬品性飞富屯。

4. 耐熱劣化性が優秀である。

耐熱性の点においては最近のイソフタル酸を用いたア ルキド樹脂る優秀であるが屈曲性の点に拈いてエポキシ エステルの方がすぐれている。ただ加熱による減量はイ ソフタル酸系の方がやや少ない上うである。その他の作 業性, 安定性, 塗膜の性状ではアルキド樹脂とほとんど 差はない。

エポキシェステルは脂肪酸の種類掞よび油長によって その性状は広範围に瓷化する。その傾向はアルキド樹脂 々全く同じである。すなわ台乾性植物油を使った油長の
長い塗料は自然乾燥性でたわみ性の大さい皮膜を形成 し，不乾性油を使った場合はアミノ樹脂などを併用して 焼付村塗料やラッカーに使われる。

エポキシエステルがアルキド樹脂と異なる点はエステ ル化度が広範囲に変えられることである。このエステル 化度は皮膜の電気的性質に影響を与兄る。すなるちエス テル化度の高いものは誘電損が小さくなる。ほた体積抵

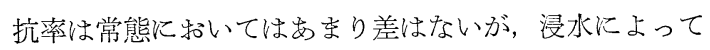
エステル化度の小さいるのは抵抗の低下が大きい。同じ エステル化度の場合には脂肪酸の種類による電気特性の 差はきわめて少ない。

次にアミノ樹脂のような架橋樹脂を加光た焼付汓塗料 に和いては, 架橋度の大きい樹脂活ど絶縁破壊電圧が高 くなる。エステル化度が高いエステルでは当然残存水酸 基が少なく，したがってある程度以上に架橋密度を上げ ることがでさない。ゆえに絶縁破壊電圧の高い塗料を造 ることがむずかしくなる。アミノ樹脂のブチル化度もか なり影響を与觉るが，その選定はミネラルスピリット特 よびメタノールトレランスが指針となる。

エポキシエステルからは多くのすぐれた絶縁塗料が得 られるが, 特に不乾性油でェステル化し, ブチル化メラ ミン樹脂を併用した焼付壮塗料は電気特性, 耐熱性が優 秀で，F種絶縁塗料としてすぐれた性能を示す。表 7 は そのワニスの特性の一例である。

不飽和脂肪酸を用いたエポキシエステルにスチレンモ ノマを重合させたスチレン化塗料はきわわて速乾性であ り，仕上げ塗料や補修用に使われる。その他アルキド樹

表 7 エポキシエステル塗料の標準性能

\begin{tabular}{|c|c|c|c|c|}
\hline 比 & 重 & $\left(20^{\circ} \mathrm{C}\right)$ & & $0.96 \pm 0.03$ \\
\hline 粘 & 度 & $\left(30^{\circ} \mathrm{C}\right)$ & ポアズ & $0.5 \sim 3.0$ \\
\hline 不揮 発 & 分 & $(\%)$ & & $45 \pm 3$ \\
\hline 酸 & 価 & (mg.K & $\mathrm{OH})$ & 10 以下 \\
\hline 硬化乾燥时 & 守間 & $(130 \pm$ & $\left.{ }^{\circ} \mathrm{C}\right)(\mathrm{h})$ & 1 以内 \\
\hline \multirow{2}{*}{\multicolumn{3}{|c|}{ 体積抵抗率 $(\Omega \mathrm{cm})$}} & 常 態 & $10^{15}$ 以上 \\
\hline & & & 浸水後 & $10^{14}$ 以上 \\
\hline \multirow{3}{*}{\multicolumn{3}{|c|}{$\begin{array}{r}\text { 絶縁破壞電压 } \\
\qquad(\mathrm{kV} / 0.1 \mathrm{~mm})\end{array}$}} & 常 態 & 9 以上 \\
\hline & & & $120^{\circ} \mathrm{C}$ & 8 以上 \\
\hline & & & 浸水後 & 7.5 以上 \\
\hline \multirow{2}{*}{\multicolumn{2}{|c|}{$\begin{array}{l}\text { 内部硬化性 } \\
\text { 耐 熱軟 化性 }\end{array}$}} & \multirow{4}{*}{\multicolumn{2}{|c|}{$\begin{array}{l}\left(120 \pm 3^{\circ} \mathrm{C}\right) \\
\left(150 \pm 3^{\circ} \mathrm{C}\right) \\
\left(170 \pm 3^{\circ} \mathrm{C}\right)= \\
\left(120 \pm 3^{\circ} \mathrm{C}\right)\end{array}$}} & 4 時間以内 \\
\hline & & & & 1 時間合格 \\
\hline 屈＼cjkstart曲 & 性 & & & 96時間以上 \\
\hline & 性 & & & 24 時間合格 \\
\hline
\end{tabular}


脂の製造に秃いて多価アルコールの一部をエポキシ樹脂 で置きか觉る方法があり，アルキド樹脂の性能向上飞有 効な方法である。

\section{8.むすび}

エポキシ樹樹の塗料化には種々の方法があり，限られ な紙面でそのすべてに触れることは不可能である。これ らの中には絶縁塗料としてすぐれたものも多い。またエ ポキシ樹脂自体多くの新しい構造のものが発表されて おり, これらを応用した優秀な絶縁塗料が出現して電気 機器の発達化大きく寄与するであるうことを期待する。
文献

1) 電気学会標準規格 JEC-147 (1960)

2) Technical Bulletin, Thiokol Chem. Corp.

3) R. J. Athey "Adiprene L, A Liquid UrethaneElastomer" Developement Product Report, No. 10, 1958, Du Pont

4) G. E., USP 2, 707, 204, 1954

5） G. E. 日本特許公告 昭 29-8194

6) J.R. Bond, S. A. Brady "Silicone Epoxy Resins in high Temperature Structural Laminates", Paper presented at the meeting of Am. Chem. Soc.. 1959

7) E. P. Plueddemann "Epoxysiloxane Casting. Resins”, Ibid, 1958.

\section{刊行物紹介}

535. 653.8

159.937. $513(038)=20$

カラー アトラス (Faver i Faver) A. Kornerup および J.H. Wanscher（デンマーク）著, 福田保 (英訳 版から）重訳, 昭和 37 年 12 月, $180 \times 125 \mathrm{~mm}, 1+2$ +94 ペ，見開き面 48 色詰色図 30 面，灰色マスク 1 枚, 大阪, 株式会社海外畫籍貿易商会刊, 灰黄色ク口ス装，色図は Sodolin \& Holmblad 社印刷，2800 円。

用紙はすべてアート紙，色図は見開き 1 面が 1 基本色 (有彩), 横に $\mathrm{A}, \mathrm{B}, \mathrm{C}, \mathrm{D}, \mathrm{E}, \mathrm{F}$ の 6 欄, 縱に 8,7 , $6,5 ， 4 ， 3 ， 2 ， 1$ の 8 段，合計 48 個の色片配列から 成る。色はすべて印刷であって最上段は基本色インキを 用いてのベタ刷り，第 2 段以下は次第に網目を粗にして 色をうすくしてゆき最下段は全くインキをつけない紙の 地色で岕る。縦の欄は右端のFに最も暗い灰色のインキ でベタ刷りをかけ， E， D， C， B と左欄に進むに従って ベタ刷りインキの灰色を明るくしてゆく。この方法で見 開き 1 面に, 基本色インキ, 灰色インキ, 特よび紙の地 色の組み合わせで 48 種の色ができる。ただし最下段の 灰色列 6 種だけは, 各面同一で山る。基本色（インキ） は 1 面 1 色で 30 面岕るから 30 色相あり, 第 1 面のレ モン黄から色相環に沿って赤側にゆき, 紫, 青, 緑と回 って若草色に終っている。色相の割りつけ方は, マンセ ルみたいな中途半端な体系構成方式にこだわらずに赤, 黄, 緑, 青のような心理原色を主点に採り, その間を適
当に分割する方式をとっているので，訳者も述べている ように「ずばり欲しい色が色票として示されて居る」と いうことにもなろう。色の総数は $42 \times 30+6=1266$ 。

色を表示するには色図面番号，欄を示す文字，段を示 す数字の順に，たとえば 27D 4 のように書く。ただし， 色票には測色值のごときものはつけてないから, 色の恒 久性とか，ばらつきとかいうことになると何子か子山な たまかせで，色の標準として使うには，はなはだたより ないものである。製作方法や本の值段を考えたら，むや みにぜい沢も言えなからう。

この本のもら一つの特色は, 英語の色名辞典の用を弁 じ，乙かも，個々の色を色図の中に求めることができる ということである。本のカバーの背に「ポケット色彩辞 典」という小書きがついているが，まったく M-P の色 彩辞典の簡約縮小版と言った観がある。（H-S)

543. 544-13(048. 8) “1961”

Gas chromatography Abstracts, 1961. C.E.M. Knapman 編, $1962,253 \times 157$ mm, X+219 ペ, London, Butterworth Publications 刊, $42 \mathrm{~s}$.

1961 年中の科学技術文献から 883 件を抄録し, 著者 索引 $(165 \sim 173$ ペ) 物よび詳細周当な事項分類索引(184. 〜219）を付けた。1958 年分以来毎 1 冊ずつ刊行されて きたもので今後も毎年続刊する予定だという。(H-S) 